\title{
Flocculation of Kaolinite Suspensions in Water by Coconut Cream Casein
}

\author{
Jacques K. Fatombi ${ }^{1,2}$, Jean-Aimé Mbey ${ }^{2}$, Taofiki Aminou ${ }^{{ }^{*}}$, Bruno Lartiges ${ }^{3}$, Nikita Topanou ${ }^{1}$, \\ Odile Barres $^{2}$, Roger G. Josse ${ }^{1}$ \\ ${ }^{1}$ Laboratory Expertise and Research in Chemistry for Water and Environment University of Abomey-Calavi, \\ Cotonou, Benin \\ ${ }^{2}$ Laboratory Environment and Mineralogy, Vandauvre-Les Nancy, France \\ ${ }^{3}$ Laboratory Geosciences Environment, Toloure, France \\ E-mail: aminoutaofiki@yahoo.fr
}

Received September 22, 2011; revised October 23, 2011; accepted November 24, 2011

\begin{abstract}
The flocculation of kaolinite colloidal particles was carried out at $\mathrm{pH}=6$ in suspension of initial turbidity varying between 24 NTU and 102 NTU by a casein extracted from Cocos nucifera cream. During Jar-test essays, $90 \%$ to $99 \%$ of colloids were eliminated in the sediments. The optimal doses of casein used depend on the initial colloids concentrations of the suspension and were found to be $60 \mathrm{mg} / \mathrm{L}$ and $100 \mathrm{mg} / \mathrm{L}$ respecttively for suspensions having turbidity of 24 NTU and 102 NTU. The corresponding residual turbidity are respectively 2.80 NTU and 10.22 NTU for clarified water. The structural analysis of the freeze-dried sediments by FTIR shows sharp adsorption bands at $1558 \mathrm{~cm}^{-1}$ and $1653 \mathrm{~cm}^{-1}$, indicating the presence of casein in the sediment. The flocculation process between the particles of kaolinite and the coconut casein is adsorption and bridging.
\end{abstract}

Keywords: Flocculation, Coconut, Casein, Kaolinite, Turbidity

\section{Introduction}

The removal of colloidal matter from water requires the use of inorganic coagulants, synthetic organic polymers or natural macromolecules. Alum is the most widely used coagulant for water treatment because of its proven performance, its effectiveness and its easy handling. Sludges produced during the water treatment with mineral salt are very abundant and not biodegradable. The presence of this mud is a risk for the environment [1]. Stauber (1999) and McLachlan (1995) [2,3] have shown that during the use of aluminum salts for water treatment, aluminum residue was dissolved in treated water and that the consumption of water containing a great quantity of aluminum salts would be involved in Alzheimer disease. Synthetic organic coagulants have the disadvantages of high price and toxicity, so their use in the production process of drinking water is limited [4].

The inorganic coagulants (aluminum and iron salts) are not produced in developing countries which import them and have consequently a high cost on the countries development process. Within the framework of sustainable development, it would be interesting to develop local resources. Natural macromolecular coagulants are the ob- ject of several researches because of their abundant source, low price, innocuous nature, multifunction and biodegradability [5]. All those properties justify the actual growing interest for natural coagulant. For example, coagulating properties were found for natural macromolecules from the aqueous extracts of dry seeds of Moringa oleifera [6-8].

The coconut palm (Cocos nucifera) is abundant in most tropical countries. We have shown during our previous work that a casein extracted from the coconut cream has flocculating properties [9]. The aim of the present study is to suggest a technology of water treatment for the destabilization and the flocculation of kaolinite suspensions using coconut cream casein. The structure of the collected and freeze-dried sediments is analyzed to appreciate the flocculation process of kaolinite particles by coconut cream casein.

\section{Material and Methods}

\subsection{Preparation of Coconut Cream Casein}

The coconuts used in this study were bought on a local market of Cotonou in Benin Republic. The ripe coconuts were dehusked and cracked to remove the water they 
contain. Hundred grams of the coconut endosperm finely worn were added to $500 \mathrm{~mL}$ of distilled water. The mixture is stirred for $10 \mathrm{~min}$ before being filtered through a sieve of $80 \mu \mathrm{m}$ porosity. The extract is formed of an aqueous phase (coconut milk) and an organic phase (coconut cream). Coconut cream casein was prepared using an isoelectric precipitation method. To $100 \mathrm{~mL}$ of coconut cream, we added hydrochloric acid $0.5 \mathrm{M}$ until total precipitation of the casein. The extracted organic fraction was centrifuged at $3500 \mathrm{trs} \cdot \mathrm{min}^{-1}$ during $20 \mathrm{~min}$ to separate the oil phase from the protein fraction. The raw casein is oven-dried at $40^{\circ} \mathrm{C}$ during 24 hours. The fats present in the raw casein were extracted with hexane using a soxlhet and the collected protein granules were powdered and labelled CaSMG. Two grams (2 g) of CaSMG were added to $100 \mathrm{~mL}$ of ultra-pure water then shaken during two hours. The obtained mixture is used as coagulant [9].

\subsection{Kaolinite Suspensions}

The kaolinite used in this study comes from Mayouom in the western Cameroon Republic. Geological origin of this kaolinite deposit was discussed by Njoya et al. (2006) [10]. The raw kaolinite was ground and wet-sieved at $<$ $40 \mu \mathrm{m}$. The granulometric analysis gives a D50 of 7.3 $\mu \mathrm{m}$ and a D90 of $23.9 \mu \mathrm{m}$. The physical and chemical characteristics of this clay are: specific surface area: 25.9 $\pm 0.1 \mathrm{~m}^{2} \cdot \mathrm{g}^{-1}$ (BET); silicon oxide: $48.28 \%$; aluminum oxide: $34.21 \%$; iron oxide: $1.97 \%$; Potassium oxide: $1.23 \%$; Titanium oxide: $3.39 \%$.

The kaolinite suspension was prepared by mixing $2 \mathrm{~g}$ of kaolinite powder in $1 \mathrm{~L}$ of ultrapure water. This mixture was stirred for $2 \mathrm{~h}$, after which it was allowed to settle for $30 \mathrm{~min}$ so that any remaining coarse particles are eliminated. The supernatant was diluted in ultrapure water containing $336 \mathrm{mg} / \mathrm{L}$ of $\mathrm{NaHCO}_{3}$ to have the turbidities wished for the jar-tests $[11,12]$. The $\mathrm{pH}$ of the colloidal suspension is adjusted to 6 using $0.1 \mathrm{~N} \mathrm{HCl}$ solution.

\subsection{Jar-Test Essays}

Jar-test essays were achieved on suspensions $S_{1}$ and $S_{2}$ with initial turbidities respectively 102 NTU and 24 NTU to evaluate coagulation activity of CaSMG. The synthetic turbid water $(100 \mathrm{~mL})$ was filled in reactors of 150 $\mathrm{mL}$ capacity. The reactors are made of beaker-glass on which four baffles in Plexiglas are fixed to avoid any whirlpool at high speed. CaSMG was added into each reactor with a Pasteur pipette $(100-1000 \mu \mathrm{L})$ at various doses and was agitated at $250 \mathrm{tr} \cdot \mathrm{min}^{-1}$ for $3 \mathrm{~min}$. The mixing speed was then reduced to $60 \mathrm{tr} \cdot \mathrm{min}^{-1}$ during 30 min. After stirring, the mixture is transferred in Imhoff cones for sedimentation during $30 \mathrm{~min}$. From each cone, $50 \mathrm{~mL}$ of the floating at $25 \mathrm{~mm}$ depth from the water surface is then taken for analysis.

On this sample, the $\mathrm{pH}$, the residual turbidity (RT sample) and the electrophoretic mobility were respecttively measured by a pH-meter WTN, a Turbidimeter HACH 2100P and a zetaphoremeter IV by CAD Instrumentation. The sediment volume was read on the Imhoff cones. Following volume measurement, the sediments were collected and freeze-dried. For infrared analysis, $1 \mathrm{mg}$ of freeze-dried sediment was mixed with $250 \mathrm{mg} \mathrm{KBr}$ and a tablet was prepared using a press connected to a vacuum pump. Fourier-Transform Infra Red (FTIR) spectroscopy was conducted in transmission mode using a Bruker system 2000 spectrophotometer. The spectra were recorded in the $4000-400 \mathrm{~cm}^{-1}$ range with 200 scans collected at $2 \mathrm{~cm}^{-1}$ resolution.

The coagulation activity was calculated based on Lee's equation [13]: coagulation activity $=$ ( RT blank RT sample)/RT blank where RT blank is the residual turbidity for the same system without coagulant.

\section{Results and Discussion}

\subsection{Fourier-Transform Infra Red (FTIR) Spectroscopy of CaSMG}

The FTIR spectrum of casein is shown on Figure 1.

On this spectrum, the amides functions characterizing the protein nature of the CaSMG are observable. The sharp absorption bands at $1649 \mathrm{~cm}^{-1}$ and $1536 \mathrm{~cm}^{-1}$ are attributed to the stretching vibration of $\mathrm{CO}$ in primary amide and secondary amide respectively [14-18]. The

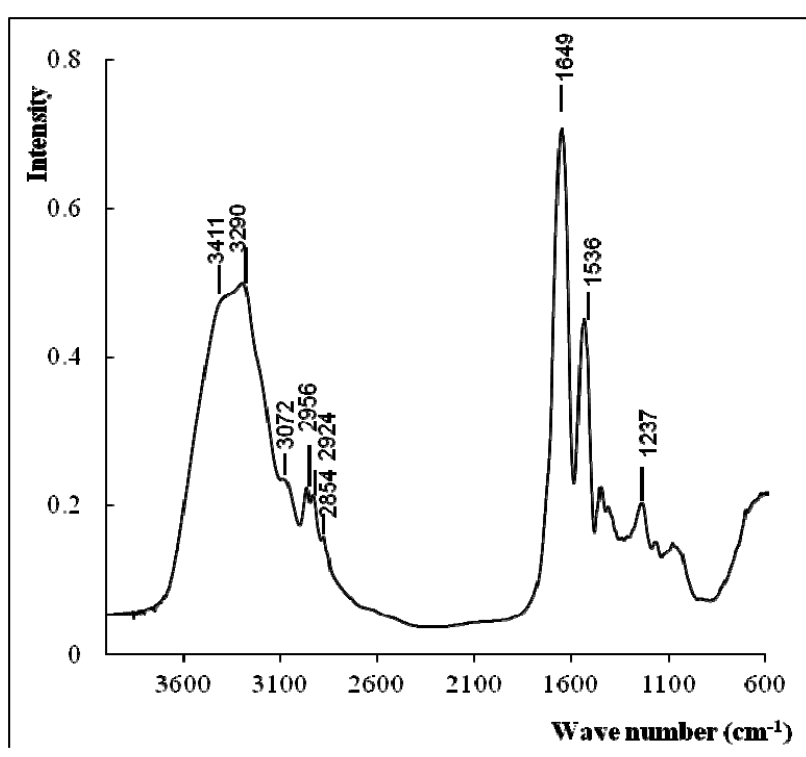

Figure 1. FTIR spectrum of CaSMG. 
wide bands at $3411 \mathrm{~cm}^{-1}$ and $3290 \mathrm{~cm}^{-1}$ are attributed to the stretching vibrations of $\mathrm{OH}$ and $\mathrm{NH}$ respectively and inter-molecular hydrogen bonds of casein [19]. The peaks appearing at $2924 \mathrm{~cm}^{-1}, 2854 \mathrm{~cm}^{-1}$ and $2956 \mathrm{~cm}^{-1}$ are assigned to the vibrating absorption of $\mathrm{C}-\mathrm{H}$ asymmetric and symmetric stretching in $\mathrm{CH}_{2}$ and $\mathrm{C}-\mathrm{H}$ asymmetric stretching in $\mathrm{CH}_{3}$ respectively [20-22]. The FTIR spectrum of CaSMG is similar to the one of active protein purified from the seeds of Moringa oleifera used for the aggregation of colloidal particles [23].

\subsection{Relationship between Turbidity, Sediment Volume and Dosage of CaSMG}

The jar-test essay carried out with the two colloidal suspensions $S_{1}$ and $S_{2}$ gave the results presented on Figures 2 and 3.

Results on Figure 2 show a variation of coagulating activity of CaSMG as function of its doses.

The coagulating activity of the suspension $S_{1}$ has increased quickly to reach $92 \%$ with $100 \mathrm{mg} / \mathrm{L}$ dose, then slowly up to $99.64 \%$ for $160 \mathrm{mg} / \mathrm{L}$ dose. In the case of the suspension $\mathrm{S}_{2}$, the coagulating activity increases up to $90 \%$ with $80 \mathrm{mg} / \mathrm{L}$ dose and decreases to $74 \%$ with higher dose of CaSMG. The observed decrease is due to kaolinite particles restructuration. These results show an important coagulating activity of the coconut casein cream and this indicates that CaSMG can be used to destabilize and flocculate the colloidal particles.

On Figure 3 a progressive decrease of water turbidities with growing doses of CaSMG is shown. The residual turbidity decrease start as first quantities of CaSMG are added to kaolinite colloidal suspensions. This obser-

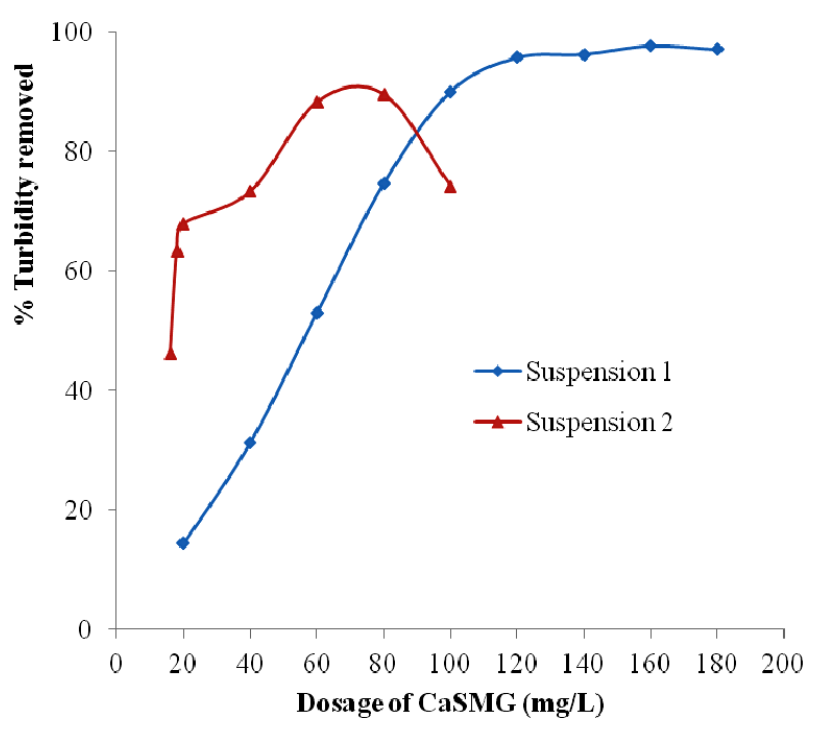

Figure 2. Effect of varying CaSMG dosage on kaolinite turbidity removal at pH 6.

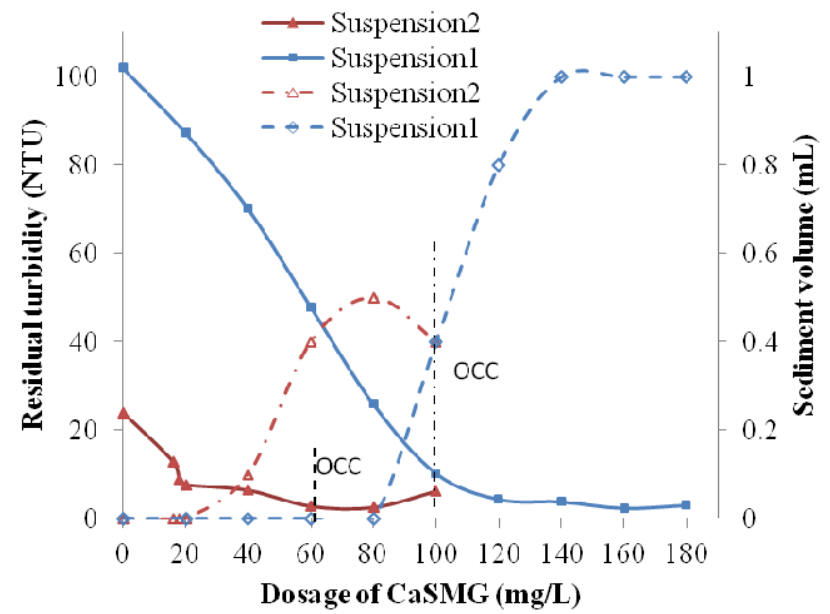

Figure 3. Effect of CaSMG dosage on residual turbidity and sediment volume at pH 6.

vation could be explained by the destabilization and flocculation of colloidal particles present in the kaolinite suspensions. These results have confirmed the flocculating properties of CaSMG [9]. The optimal doses depend on the initial suspension turbidity and were found to be 100 $\mathrm{mg} / \mathrm{L}$ and $60 \mathrm{mg} / \mathrm{L}$ respectively for $\mathrm{S}_{1}$ and $\mathrm{S}_{2}$ suspensions. The coagulating-flocculating activities are $92 \%$ for $\mathrm{S}_{1}$ and $88 \%$ for $S_{2}$. No restabilization of kaolinite particles has been noted at the level of suspension $S_{1}$ whereas this phenomenon occurred for the suspension $S_{2}$. In fact, an increase of the residual turbidity has been noted for the jar-test essays carried out with $\mathrm{S}_{2}$ for the dosage of casein superior to $80 \mathrm{mg} / \mathrm{L}$.

The sediments volumes were less than $0.1 \mathrm{~mL}$ with CaSMG doses less than $80 \mathrm{mg} / \mathrm{L}$ for $S_{1}$ and $20 \mathrm{mg} / \mathrm{L}$ for $S_{2}$. For CaSMG doses higher than $80 \mathrm{mg} / \mathrm{L}$ for $\mathrm{S}_{1}$ and 20 $\mathrm{mg} / \mathrm{L}$ for $\mathrm{S}_{2}$, one could notice increases of sediments volumes of $1 \mathrm{~mL}$ for $\mathrm{S}_{1}$ and $0.5 \mathrm{~mL}$ for $\mathrm{S}_{2}$ and the corresponding doses were $140 \mathrm{mg} / \mathrm{L}$ for $S_{1}$ and $80 \mathrm{mg} / \mathrm{L}$ for $S_{2}$. The sediments volumes were then decreased for doses of casein higher than $80 \mathrm{mg} / \mathrm{L}$ for $\mathrm{S}_{2}$. This decrease of sediment volume is related to a restabilization process of colloidal particles. The quantities of sediments collected depend on the colloids contained in the various suspensions.

\section{3. pH Variation of Treated Water}

The variation of the treated water $\mathrm{pH}$ is shown on Figure 4.

On Figure 4, a slight decrease of $\mathrm{pH}$ proportional to casein doses, is observed for the treated water. The decrease of $\mathrm{pH}$ was approximately 0.5 and 0.9 unit $\mathrm{pH}$ for $\mathrm{S}_{2}$ and $\mathrm{S}_{1}$ respectively. The $\mathrm{pH}$ decrease is negligible. 


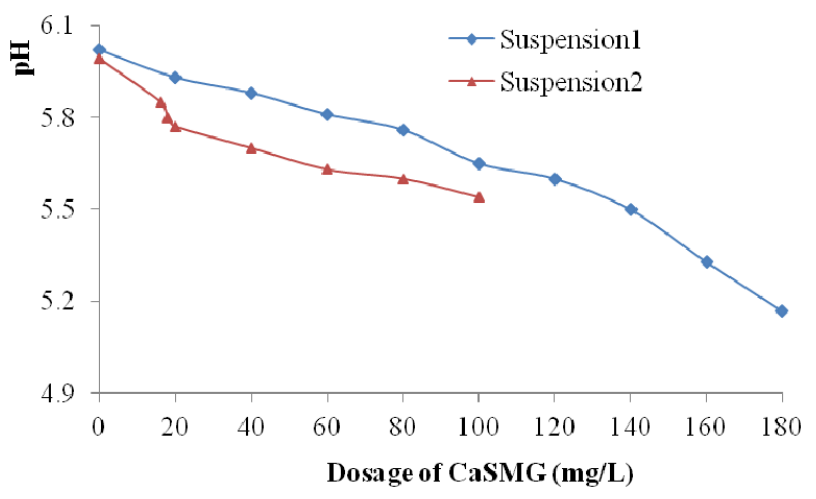

Figure 4. Effect of CaSMG dosage on pH.

\subsection{Transmission Fourier-Transform Infra Red (FTIR) Spectroscopy of Freeze-Dried Sediments}

The FTIR spectra of $\mathrm{S}_{1}$ sediments freeze-dried are represented on Figure 5. The main observed peaks and their corresponding characteristics are summarized in Table 1.

On Figure 5, the FTIR spectra of the sediment due to kaolinite and casein aggregation are presented. The spectra indicate the relative intensities variation of peaks as function of CaSMG doses. The characteristics vibration modes of kaolinite and CaSMG vibrations are observable and this is a proof of the fact that the sediments contain both kaolinite and CaMSG. On these spectra, we notice broad and intense bands at $1032 \mathrm{~cm}^{-1}, 1007 \mathrm{~cm}^{-1}$ and $1115 \mathrm{~cm}^{-1}$ which are characteristic Si-O bond vibration in kaolinite. Moreover, new peaks were observed at 2961

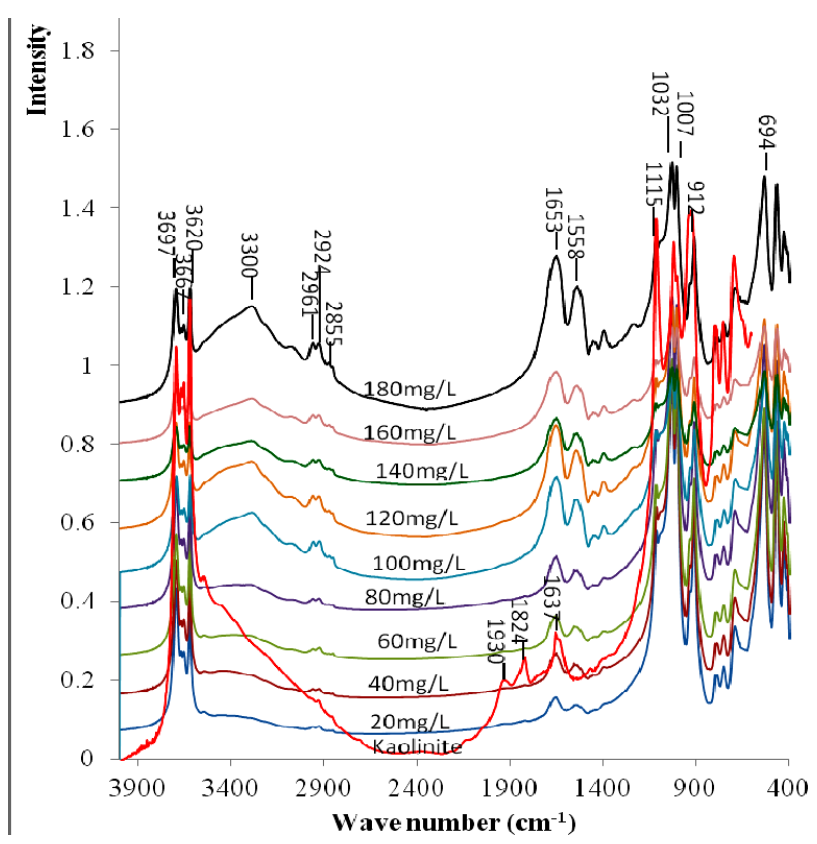

Figure 5. FTIR spectra of freeze-dried sediment as a function of CaSMG doses (Suspension $\mathrm{S}_{1}$ ).
Table 1. Fourier Transformed Infra Red bonds of freezedried sediments of kaolinite flocculation by casein.

\begin{tabular}{|c|c|c|c|}
\hline \multicolumn{2}{|c|}{ Bond $\left(\mathrm{cm}^{-1}\right)$} & \multirow{2}{*}{ Assignment } & \multirow{2}{*}{ Reference } \\
\hline $\mathrm{a}$ & b & & \\
\hline \multicolumn{4}{|c|}{36953697} \\
\hline 3667 & 3667 & OH stretching bands in kaolinite & {$[24,25]$} \\
\hline \multicolumn{4}{|c|}{36523652} \\
\hline \multirow[t]{7}{*}{3620} & 3620 & & \\
\hline & 3400 & $\mathrm{OH}$ vibration and with a partial contribution of $\mathrm{N}-\mathrm{H}$ & $-\mathrm{H} \quad[19]$ \\
\hline & 2961 & $\mathrm{C}-\mathrm{H}$ asymmetric stretching in $\mathrm{CH}_{3}$ & [20] \\
\hline & 2924 & $\mathrm{C}-\mathrm{H}$ asymmetric stretching in $\mathrm{CH}_{2}$ & [21] \\
\hline & 2855 & $\mathrm{C}-\mathrm{H}$ symmetric stretching in $\mathrm{CH}_{2}$ & [22] \\
\hline & $1653 \varsigma$ & Strong $\mathrm{C}=\mathrm{O}$ asymmetric stretching in amide $\mathrm{I}$ & [18] \\
\hline & 1558 & $\mathrm{C}=\mathrm{O}$ asymmetric stretching in amide $\mathrm{I}$ & [18] \\
\hline 1114 & 1115 & & \\
\hline \multirow[t]{2}{*}{1120} & 1032 & Si-O vibration in siloxane or silica & {$[24,26]$} \\
\hline & 1007 & & \\
\hline 924 & 912 & Al-OH vibration & {$[24,27]$} \\
\hline 796 & 797 & & \\
\hline 752 & 751 & & \\
\hline 700 & 694 & Vibration Gibbsite-like layer of kaolinite & {$[24,27]$} \\
\hline
\end{tabular}

a: kaolinite; b: freeze-dried sediment.

$\mathrm{cm}^{-1}, 2924 \mathrm{~cm}^{-1}$ and $2855 \mathrm{~cm}^{-1}$ characterizing the C-H bond vibration in $\mathrm{CH}_{2}$ and $\mathrm{CH}_{3}$ contained in CaSMG residues (Figure 1). The intense band at $1653 \mathrm{~cm}^{-1}$ and $1558 \mathrm{~cm}^{-1}$ is assigned to $\mathrm{C}=\mathrm{O}$ vibration in amides $\mathrm{I}$ and II. The large band at $3300 \mathrm{~cm}^{-1}$ is assigned to hydrogen bonds between $\mathrm{OH}$ and $\mathrm{NH}$ within the sediment. The bands at $1930 \mathrm{~cm}^{-1}, 1824 \mathrm{~cm}^{-1}$ and $1637 \mathrm{~cm}^{-1}$ on the pure kaolinite spectrum are combination bands due to bending and in plane vibrations mode of water. This band disappears on the sediments spectra because of the freeze drying process used to eliminate water in the sediment. A simultaneous elimination of kaolinite and residues of casein, therefore occurred during the flocculation process.

During the destabilization process of kaolinite suspensions, the quantity of aggregated colloids of kaolinite and of the residues of casein eliminated increase with the dose of casein introduced into the suspension. As a matter of fact, the intensity of the peaks correspond to C-H, $\mathrm{C}=\mathrm{O}$ and $\mathrm{Si}-\mathrm{O}$ bonds vibrations progressively increase (Fi- gure 5).

The sediment spectra (Figure 5) show that the aggregation of particles of kaolinite has not modified the structure of the casein as well as the one of the aggregated kaolinite. An apparition of new functions has not been noted on the spectra, which implies that the flocculation process of kaolinite particles by the casein is an adsorption of particles of kaolinite on the chains of casein macromolecules and thanks to its $\alpha$-helice, structure, the micro flocs formed are related, one to another, by hy- 
drogen bonds, which permits to form stable aggregates that flocculate.

The relative abundance of $\mathrm{CH}_{2} / \mathrm{CH}_{3}$, $\mathrm{CO}$ and $\mathrm{Si}-\mathrm{O}$ in the freeze-dried sediments as a function of the CaSMG doses were characterized by the following ratios of peaks intensities: $I_{2961} / I_{2924}, I_{1558} / I_{1653}$ and $I_{1007} / I_{1032}$ where 2961 $\mathrm{cm}^{-1}, 2924 \mathrm{~cm}^{-1}$ correspond to C-H asymmetric stretching in $\mathrm{CH}_{2}$ and $\mathrm{C}-\mathrm{H}$ symmetric stretching in $\mathrm{CH}_{3}$ respectively, $1653 \mathrm{~cm}^{-1}$ and $1558 \mathrm{~cm}^{-1}$ correspond to $\mathrm{C}=\mathrm{O}$ asymmetric stretching in amides I and II respectively, 1032 $\mathrm{cm}^{-1}$ and $1007 \mathrm{~cm}^{-1}$ correspond to Si-O stretching.

The Figure 6 shows that the ratio $I_{1007} / I_{1032}$ is practically constant when the CaSMG doses varying between $20 \mathrm{mg} / \mathrm{L}$ and $80 \mathrm{mg} / \mathrm{L}$ and increase for doses higher than $80 \mathrm{mg} / \mathrm{L}$. At the optimal dose $(100 \mathrm{mg} / \mathrm{L})$, the ratio value is 0.99 in the freeze-dried sediment. The initial value of this ratio in the pure kaolinite is 1.04 . Hence, approximately $95 \%$ of kaolinite colloids present in the $S_{1}$ suspension are eliminated at the optimal dose. These results confirm those obtained with jar-test essays (Figure 2) and show that the kaolinite particles flocculation started by adding the first doses of casein.

The ratio $I_{2961} / I_{2924}$ is high in the freeze-dried sediments at the beginning of experiment (doses of casein under $40 \mathrm{mg} / \mathrm{L}$ ). Then, the ratio decrease drastically when the casein doses varies between $40 \mathrm{mg} / \mathrm{L}$ and $80 \mathrm{mg} / \mathrm{L}$ with a value reached 0.88 for $80 \mathrm{mg} / \mathrm{L}$ and the sediment volume less than $0.1 \mathrm{~mL}$ (Figure 3). For casein doses higher than $80 \mathrm{mg} / \mathrm{L}$, we observe a continuous increase of the ratio till 1.01 for $120 \mathrm{mg} / \mathrm{L}$. Beyond this dose, we notice a decrease of the ratio which then become constant.

The ratios $I_{1558} / I_{1653}$ and $I_{2961} / I_{2924}$ have the same trends. These ratios are related to vibrations mainly due to

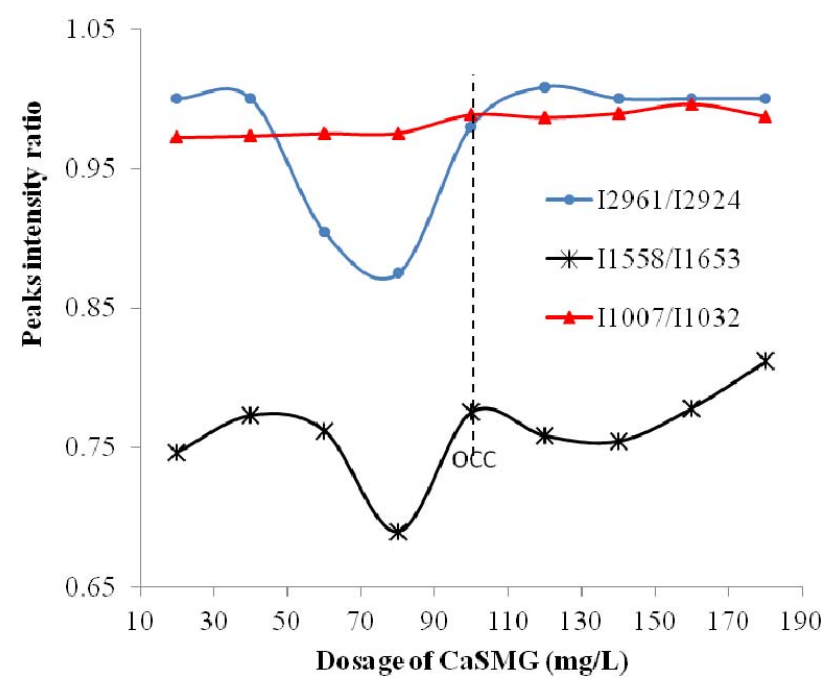

Figure 6. Variation of peak intensity ratio $I_{1007} / I_{1032}, I_{1558} /$ $I_{1653}$ and $I_{2961} / I_{2924}$ as function of CaSMG doses (Suspension $\left.\mathrm{S}_{1}\right)$. casein presence within the sediment. Hence the increase of the ratio $I_{1558} / I_{1653}$ for CaSMG dosage greater than 140 $\mathrm{mg} / \mathrm{L}$ is due to excess CaSMG. Therefore, this is a proof that the residual casein is eliminated from the system and could be in the mud. The mud obtained during jar-tests are rich with organic matters and the presence of kaolinite particles embedded within this organic matter is good evidence of kaolinite-CaSMG association with the aggregates.

\subsection{Destabilization Mechanism}

The result presented on Figure 7 show that the electrophoretic mobility of the particles in the treated water are negative. For the CaSMG doses used, a neutralization of the charge was not observed. The value of the electrophoretic mobility decrease in absolute value indicating that the casein used is a cationic polyelectrolyte. This conclusion is in accordance with the measured electrophoretic mobility of a solution of CaSMG $(40 \mathrm{mg} / \mathrm{L})$ that was $+0.34 \mu \mathrm{S} / \mathrm{s} / \mathrm{V} / \mathrm{cm}$ at a $\mathrm{pH}$ around 7 . Giving that the particles of kaolinite are negatively charged, then, the coagulation process of the kaolinite suspension using CaSMG is caused by the destabilization of negatively charged colloids by cationic polyelectrolyte. However, from the fact that the electrophoretic mobility was not reduced to zero, then the mechanism of the particles of kaolinite flocculation process is not charge neutralization but rather through adsorption and bridging or heterocoagulation [28].

\section{Conclusions}

The aggregation process of kaolinite particles by CaSMG started as soon as first portions of casein were added. The value of optimal doses depends on initial turbidities of the colloidal suspensions to be destabilized and floc-

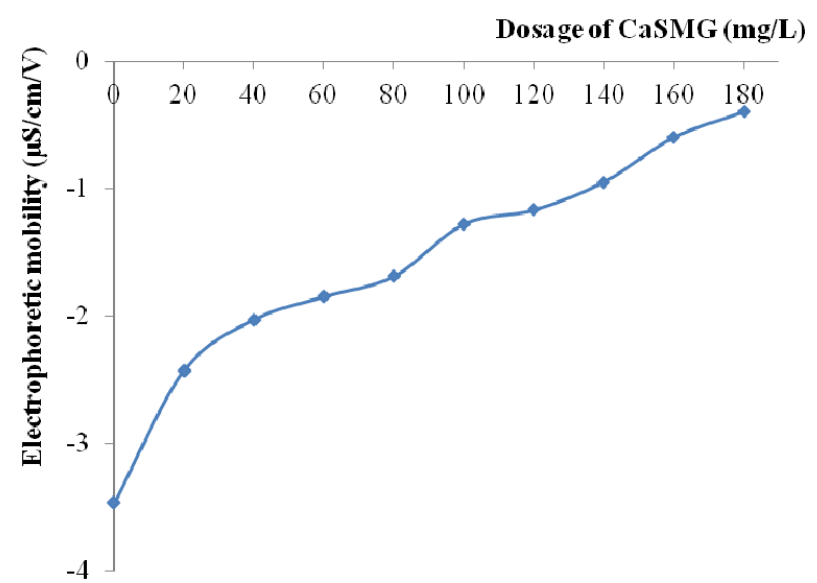

Figure 7. Variation of electrophoretic mobility of treated water at pH 6 (Suspension 1). 
culated. $\mathrm{pH}$ of treated water decrease proportionately to the casein doses but remain negligible. The collected sediments are biodegradable due to the biodegradability of the coagulating agent. During flocculation process, 90 to $99 \%$ of colloidal particles are eliminated in the sediments. The colloids and casein residues are eliminated simultaneously. The particles of kaolinite are surrounded by the macromolecules of casein and the aggregation process is achieved by adsorption and bridging or heterocoagulation between the two charged particles.

The coconut casein is a coagulant and a rather successful flocculant. Furthermore, its natural origin makes it an economic and ecological agent because it is biodegradable, not toxic and generates less sediment than the use of alum. The casein from coconut cream appears as a good substitute or alternative to salts of aluminum and other synthetic polyelectrolytes in water treatment. The residual muds can be used as organic amendment on agricultural lands.

\section{Acknowledgements}

We thank the "Agence Universitaire de la Francophonie" (AUF) for granting a post doctoral research allowance fellowship to Jacques K. FATOMBI, Laboratoire Environnement et Minéralurgie (LEM), Department of English studies (University of Parakou-Benin).

\section{References}

[1] C. T. Driscoll and R. D. Letterman, "Factors Regulating Residual Aluminum Concentrations in Treated Waters," Environmetrics, Vol. 6, No. 3, 1995, pp. 287-305. doi:10.1002/env.3170060306

[2] J. L. Stauber, T. M. Florence, C. M. Davies, M. S. Adams and S. J. Buchanan, "Bioavailability of Al in Alum Treated Drinking Water," Journal of American Water Works Association, Vol. 91, No. 11, 1999, pp. 84-93.

[3] D. R. C. McLachlan, "Aluminum and the Risk for Alzheimer's Disease,” Environmetrics, Vol. 6, No. 3, 1995, pp. 233-275. doi:10.1002/env.3170060303

[4] Z. Lu, "Medicament of Water Treatment," Publishing Company of Chemical Industry, Beijing, 2002, pp. 100-102.

[5] B. Bolto and J. Gregory, "Organic Polyelectrolytes in Water Treatment," Water Research, Vol. 41, No. 11, 2007, pp. 2301-2324. doi:10.1016/j.watres.2007.03.012

[6] T. Okuda, A. U. Baes, W. Nishijima and M. Okada, “A Isolation and Characterization of Coagulant Extracted from Moringa oleifera Seed by Salt Solution," Water Research, Vol. 32, No. 2, 2001, pp. 405-410. doi:10.1016/S0043-1354(00)00290-6

[7] K. A. Ghebremichael, K. R. Gunaratna, H. Henriksson, H. Brumer and G. Dalhammar, "A Simple Purification and Activity Assay of the Coagulant Protein from Moringa oleifera Seed," Water Research, Vol. 39, No. 11, 2005, pp. 2338-2344. doi:10.1016/j.watres.2005.04.012

[8] H. M. Kwaambwa, M. Hellsing and A. R. Rennie, “Adsorption of a Water Treatment Protein from Moringa oleifera Seeds to a Silicon Oxide Surface Studied by Neutron Reflection,” Langmuir, Vol. 26, No. 6, 2010, pp. 3902 3910. doi:10.1021/la9031046

[9] K. J. Fatombi, R. G. Jossè, D. Mama and T. Aminou, "Etude de l'Activité Floculante de la Caséine Acide de la Crème de Cocos nucifera sur la Clarification des Eaux de Surface,” Revue des Sciences de l'Eau, Vol. 22, No. 1, 2009, pp. 93-101.

[10] A. Njoya, C. Nkoumbou, C. Grosbois, D. Njopwouo, D. Njoya, A. Courtin-Nomade, J. Yvon and F. Martin, “Genesis of Mayouom Kaolin Deposit (Western Cameroon)," $A p$ plied Clay Science, Vol. 32, No. 1-2, 2006, pp. 125-140. doi:10.1016/j.clay.2005.11.005

[11] J. M. Siéliéchi, B. S. Lartiges, G. J. Kayem, S. Hupont, C. Frochot, J. Thieme, J. Ghanbaja, J. B. d'Espinose de la Caillerie, O. Barrès, R. Kamga, P. Levitz and L. J. Michot, "Changes in Humic Acid Conformation during Coagulation with Ferric Chloride: Implications for Drinking Water Treatment," Water Research, Vol. 42, No. 8-9, 2008, pp. 2111-2123. doi:10.1016/j.watres.2007.11.017

[12] A. Ndabigengesere, K. Narasiah and B. G. Talbot, “Active Agents and Mechanisms of Coagulation of Turbid Water Using Moringa oleifera,” Water Research, Vol. 29, No. 2, 1995, pp. 703-710. doi:10.1016/0043-1354(94)00161-Y

[13] S. H. Lee, S. O. Lee, K. L. Jang and T. H. Lee, "Microbial Flocculant from Arcuadendron SP-49,” Biotechnological Letters, Vol. 17, No. 1, 1995, pp. 95-105.

[14] A. Dong, J. Matsuura, S. D. Allison, E. Chrisman, M. C. Manning and J. F. Carpenter, "Infrared and Circular Dichroism Spectroscopic Characterization of Structural Differences Between-Lactoglobulin A and B," Biochemistry, Vol. 35, No. 5, 1996, pp. 1450-1457.

[15] H. Dave, A. Troullier, I. Mus-Veteau, M. Dunach, G. Leblanc and E. Padros, "Secondary Structure Components and Properties of The Melibiose Permease from Escherichia coli: a Fourier Transform Infrared Spectroscopy Analysis," Biophysical Journal, Vol. 79, No. 2, 2000, pp. 747-755. doi:10.1016/S0006-3495(00)76332-6

[16] V. Cabiaux, K. A. Oberg, P. Pancoska, T. Walz, P. Agre and A. Angel, "Secondary Structures Comparison of Aquaporin-1 and Bacteriorhodopsin: A Fourier Transform Infrared Spectroscopy Study of Two-Dimensional Membrane Crystals,” Biophysical Journal, Vol. 73, No. 1, 1997, pp. 406-417. doi:10.1016/S0006-3495(97)78080-9

[17] S. J. Prestrelski, N. Tedeschi, T. Arakawa and J. F. Carpenter, "Dehydration-Induced Conformational Transitions in Proteins and Their Inhibition by Stabilizers," Biophysical Journal, Vol. 65, No. 2, 1993, pp. 661-671. doi:10.1016/S0006-3495(93)81120-2

[18] J. T. Pelton and L. R. McLean, "Review of Spectroscopic Methods for Analysis of Protein Secondary Structure," Analytical Biochemistry, Vol. 277, No. 2, 2000, pp. 167176. doi:10.1006/abio.1999.4320 
[19] J.-P. Wang, Y.-Z. Chen, S.-J. Yuan, G.-P. Sheng and H.-Q. $\mathrm{Yu}$, "Synthesis and Characterization of a Novel Cationic Chitosan-Based Flocculant with a High Water-Solubility for Pulp Mill Wastewater Treatment," Water Research, Vol. 43, No. 20, 2009, pp. 5267-5275. doi:10.1016/j.watres.2009.08.040

[20] B. Gu, J. Schmitt, Z. Chen, L. Liang and J. McCarthy, "Adsorption and Desorption of Natural Organic Matter on Iron Oxide: Mechanisms and Models," Environmental Science \& Technology, Vol. 28, No. 1, 1994, pp. 38-48. doi:10.1021/es00050a007

[21] M. F. Dignac, S. Derenne, P. Ginertet, A. Bruchet, H. Knicker and C. Largeau, "Determination of Structure and Origin of Refractory Organic Matter in Bio-Epurated Wastewater via Spectroscopic Methods. Comparaison of Conventional and Ozonation Treatments," Environmental Science \& Technology, Vol. 34, No. 16, 2000, pp. 33893394. doi:10.1021/es9913838

[22] A. G. El Samrani, B. S. Lartiges, E. Montagès-Pelletier, V. Kazparg, O. Barrès and J. Ghanbaja, "Clarification of Municipal Sewage with Ferric Chloride: The Nature of Coagulant Species,” Water Research, Vol. 38, No. 3, 2004, pp. 756-768. doi:10.1016/j.watres.2003.10.002

[23] H. M. Kwambwa and R. Maikokera, "Infrared and Circular Dichroism Spectroscopic Characterisation of Secondary Structure Components of a Water Treatment Co- agulant Protein Extracted from Moringa oleifera Seeds," Colloids Surf. B: Biointerface, Vol. 64, No. 1, 2008, pp. 118-125. doi:10.1016/j.colsurfb.2008.01.014

[24] S. Olejnik, L. A. G. Aylmore, A. M. Posner and J. P. Quirk, "Infrared Spectra of kaolin Mineral-Dimethyl Sulfoxide Complexes," Journal of Physical Chemistry, Vol. 72, No. 1, 1968, pp. 241-249. doi:10.1021/j100847a045

[25] H. Marel and H. Beutelspacher, "Atlas of Infrared Spectroscopy of Clay Minerais and Their Admixtures,” Elsevier Scientific, Amsterdam, 1976, p. 396.

[26] J. Coates, "Interpretation of Infrared Spectra, a Practical Approach,” In: R. A. Meyers, Ed., Encyclopedia of Analytical Chemistry, John Wiley \& Sons Ltd, Chichester, 2000, pp. 10815-10837.

[27] B. A. Imene and S. Ezzeddine, "Synthèse et Caractérisation d'un Hybride Organique-Inorganique à Partir d'une Argile Tunisienne par une Réaction à l'état Solide," African Journal of Science and Techology, Vol. 9, No. 1, 2008, pp. 2-19.

[28] A. G. El Samrani, N. Ouaini, V. Kazpard and Z. Saad, "Influence des Ligands Phosphatés sur le Mécanisme de Déstabilisation de Particules Colloïdales de Silice par le Chlorure Ferrique,” Lebanese Science Journal, Vol. 7, No. 1, 2006, pp. 103-112. 